\title{
Spectrophotometric determination of $\mathrm{Ce}$ (IV) using $o$-phenylenediamine in steels
}

\author{
ARCHANA AGRA WAL*, K CHANDRA SEKHAR and L P PANDEY \\ Analytical Chemistry Division, National Metallurgical Laboratory, Jamshedpur 831007 , \\ India \\ MS received 21 December 1993; revised 11 July 1994

\begin{abstract}
A simple and sensitive spectrophotometric method for the determination of cerium(IV) was developed. With $o$-phenylenediamine cerium(IV) gives an orange-red colour with an absorption maximum at $470 \mathrm{~nm}$. The system obeys Beer's law in the range $7 \mathrm{ppm}$ to $500 \mathrm{ppm}$ with a molar absorptivity of $2.4 \times 10^{3} 1 \mathrm{~mol}^{-1} \mathrm{~cm}^{-1}$ and Sandell sensitivity of $0.5 \mathrm{ppm}$. Interference by various ions was studied. This method was used for the determination of cerium in low-alloy steels and the results are in good agreement with the certified values.
\end{abstract}

Keywords. Cerium; O-phenylenediamine; Ce(IV) in steel; spectrophotometry.

\section{Introduction}

In a review of the literature on rare-earth additions to steel, Anderson and Spreadborough (1967) concluded that rare earths improve the quality and some mechanical properties of various types of steels, but that the exact effect depends on the nature of the steel. In general rare-earth additions to low-alloy steels improve the mechanical and plastic properties, besides acting as strong desulfurizing and deoxidizing agents (Kippenhan and Gschneidner 1970); whereas oxidation resistance and scaling resistance increase in the case of high-alloy steels. Addition of cerium alone increases the life of the steel. The amount of cerium added is critical and an excess is reported to have an adverse effect on high-temperature properties of steel (Trusou et al 1963).

The unique similarity in the chemical properties of the rare-earth group of elements has led to reliance on measurements of physical properties in order to obtain analytical data on mixtures of these elements. Various spectroscopic techniques have proven to be very useful (Fassel 1960) and among these optical emission spectroscopy has been the most widely used. However, the arc and spark emission spectra of the rare-earth elements are very complex and often consist of thousands of lines. As a result, line interferences are frequent and, even when high-dispersion instruments are used, interlerence-free lines are often difficult to find. Investigators were therefore led to explore the analytical capabilities of conventional flame which produces less complex spectra (Dean and Rains 1975).

Despite various attempts, it was not possible to determine cerium by atomic absorption spectroscopy (AAS) for a long period (Welz 1985). Kinnunen and Lindsjoe (1967) emp asized the difficulties in locating the proper rare-earth absorption line because of the complexity of the spectra emitted by hollow cathode lamps. They also reported that absorbance of several of the rare-earth elements was depressed significantly in the presence of fluoride and silicon. An indirect method (amplification

* For correspondence 
reaction) has been reported for cerium by measuring molybdenum in molybdocerophosphoric acid by AAS (Johnson et al 1973).

Traces of cerium are determined by titrimetric, kinetic, spectrophotometric (Sarma 1956; Papa et al 1959; Zhivopistsev and Parkacheva 1963; Pollock 1969; Arora et al 1980) and fluorimetric methods (Armstrong et al 1963; Kirkbright et al 1965, 1966; Cukor and Weberling 1968; Pal et al 1977; Poluektov et al 1970). Spectrophotometric determination in the visible range is best suited in routine analysis as the results are reproducible and the colour change can be conspicuously seen. A number of reagents are available for the spectrophotometric determination of cerium, such as brucine (Shemyakin and Volkova 1939), thenoyltrifluoroacetone (Hiroshi and Yukio 1965) and salicylhydroxime (Poddar et al 1965).

$o$-Phenylenediamine gives an orange colour with cerium(IV). The reaction is very sensitive and the colour is stable for quite a long time. $\mathrm{Ce}$ (III) does not give this test and hence does not interfere. A study of the above reaction was made for the spectrophotometric determination of $\mathrm{Ce}(\mathrm{IV})$ and the results are presented in this paper.

\section{Experimental}

\subsection{Apparatus}

Absorbance measurements were made with a Shimadzu 2100 S double beamUV-Vis spectrophotometer. $\mathrm{pH}$ measurements were made on a Unitech UI-11p pH meter.

\subsection{Reagents}

All reagents were of analytical reagent grade unless specified otherwise.

Cerium(IV) stock solution: $0.288 \mathrm{~g}$ of cerium(IV) sulphate was dissolved in $5 \mathrm{ml}$ of sulphuric acid and made up to $100 \mathrm{ml}$ to make a stock solution of $1000 \mathrm{ppm}$ of $\mathrm{Ce}$ (IV). The solution was standardized gravimetrically (Vogel 1961).

$o$-Phenylenediamine (OPD) solution: $0.1 \%$ solution of the reagent was prepared by dissolving $100 \mathrm{mg}$ of OPD (Koch-Light Laboratories Ltd, England) in $100 \mathrm{ml}$ of distilled water and stored in an amber glass bottle.

\subsection{Procedure}

To $5 \mathrm{ml}$ of $0.1 \%$ reagent (OPD) $2 \mathrm{ml}$ of $1 \mathrm{M} \mathrm{H}_{2} \mathrm{SO}_{4}$ was added and the mixture was shaken well for $2 \mathrm{~min}$. One $\mathrm{ml}$ of $\mathrm{Ce}$ (IV) solution containing $7 \mathrm{ppm}$ to $500 \mathrm{ppm}$ was added to the above solution. The mixture was made up to $10 \mathrm{ml}$ with water and kept for $10 \mathrm{~min}$ to ensure complete reaction. The absorbance of the orange-red solution was measured against a similarly prepared reagent blank at $470 \mathrm{~nm}$.

\section{Results and discussion}

The orange-red colour develops immediately on addition of reagent and the product is stable for $24 \mathrm{~h}$. 
$\mathrm{Ce}(\mathrm{IV})-\mathrm{OPD}$ mixture showed maximum absorbance in the range $1 \mathrm{M}$ to $3 \mathrm{M}$ of $\mathrm{H}_{2} \mathrm{SO}_{4}$ after which the absorbance decreased. Five $\mathrm{ml}$ of $0.1 \%$ reagent was found to give maximum absorbance above which there was no significant increase in the absorbance.

The absorption spectrum of orange-red $\mathrm{Ce}(\mathrm{IV})$ and $\mathrm{OPD}$ products shows maximum absorbance at $470 \mathrm{~nm}$, with a molar absorptivity of $2.4 \times 10^{3} 1 \mathrm{~mol}^{-1} \mathrm{~cm}^{-1}$. The system obeys Beer's law in the range $7 \mathrm{ppm}$ to $500 \mathrm{ppm}$. Sandell sensitivity (Sandell 1959) of the colour was found to be $0.5 \mathrm{ppm}$ of Ce(IV) at $470 \mathrm{~nm}$.

\subsection{Effect of diverse ions}

Effect of various ions on the determination of Ce(IV) by this method was examined. Fifty-fold excess of citrate, oxalate and tartrate showed no interference. Acetate, fluoride, phosphate, bromate, iodate, chloride, sulphate, nitrate, acetate and thiourea did not interfere. Hundred-fold excess of $\mathrm{Pb}, \mathrm{Cd}, \mathrm{Mn}, \mathrm{Al}, \mathrm{Ti}, \mathrm{Mo}, \mathrm{W}$ and $\mathrm{U}$; fifty-fold excess of $\mathrm{Co}, \mathrm{Ni}$ and $\mathrm{Zn}$; and twenty-fold excess of $\mathrm{Bi}, \mathrm{Sn}, \mathrm{Zr}$ and $\mathrm{Th}$ did not interfere. $\mathrm{Cu}(\mathrm{II}), \mathrm{Fe}(\mathrm{III}), \mathrm{Cr}(\mathrm{III})$ and EDTA interfered seriously. Ce(III), La(III), Gd(III), $\mathrm{Nd}(\mathrm{III}), \mathrm{Ho}(\mathrm{III}), \mathrm{Yb}(\mathrm{III})$ and $\mathrm{Dy}(\mathrm{III})$ did not interfere.

\subsection{Precision}

The precision of the determination of $\mathrm{Ce}(\mathrm{IV})$ by the present method was evaluated by analysing replicate samples containing different concentrations of $\mathrm{Ce}$ (IV) (each determination was carried out six times). The relative standard deviation in the range 2.51-1.02 for $250-100 \mathrm{ppm}$ of $\mathrm{Ce}(\mathrm{IV})$ indicates that the method is very precise.

\subsection{Composition and mechanism}

Job's (1928) method of continuous variation shows no complex formation which is also confirmed by IR spectra. Hence the most possible mechanism can be the oxidation of OPD by $\mathrm{Ce}(\mathrm{IV})$. The oxidation product formed can be a diaminephenazene. The possible reaction is:

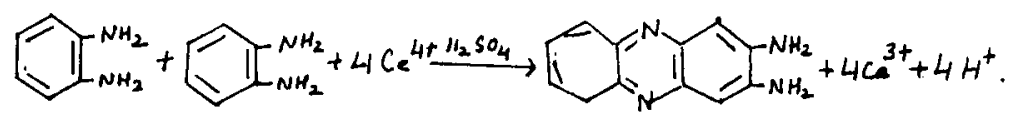

\section{Analytical application}

Dissolution of steels: Weigh $(0 \cdot 25 \mathrm{~g})$ of the steel sample and transfer it to $250 \mathrm{ml}$ beaker. Add $30 \mathrm{ml}$ of $\mathrm{HCl}$ (sp. gr. 1.13) and heat till sample is dissolved. Add $\mathrm{HNO}_{3}$ dropwise continuously, avoiding any excess, until iron is just oxidized, indicated by slight effervescence. Boil the solution till the fumes are clear. Cool the solution. Iron and manganese were separated (Luke 1966; Burkin 1980) prior to the determination of $\mathrm{Ce}(\mathrm{IV})$. The solution (free from iron and manganese) was boiled with $\mathrm{H}_{2} \mathrm{SO}_{4}$ and $\left(\mathrm{NH}_{4}\right)_{2} \mathrm{~S}_{2} \mathrm{O}_{4}$ so as to ensure complete oxidation of $\mathrm{Ce}$ (III) to $\mathrm{Ce}$ (IV). $\mathrm{Ce}$ (IV) in the 
Table 1. Analysis of low-alloy steels for cerium.

\begin{tabular}{|c|c|c|c|}
\hline \multirow[b]{2}{*}{ Steel sample/composition $(\%)$} & \multirow[b]{2}{*}{$\begin{array}{l}\text { Certified } \\
\text { value }(\%)\end{array}$} & \multicolumn{2}{|c|}{ Cerium found $*(\%)$} \\
\hline & & $\begin{array}{l}\text { Present } \\
\text { method }\end{array}$ & $\mathrm{AAS}^{\#}$ \\
\hline (A) ST02-1 & 0.0580 & 0.0562 & 0.0578 \\
\hline \multicolumn{4}{|l|}{$\begin{array}{l}C=0.101 ; \mathrm{Si}=0.64 ; \mathrm{Mn}=0.22 \\
\mathrm{~S}=0.0048 ; \mathrm{Cu}=0.070 ; \mathrm{Ni}=0.082 \\
\mathrm{Cr}=4.10 ; \mathrm{Mo}=0.53 ; \mathrm{V}=0.41 \\
\mathrm{Ti}=0.029 ; \mathrm{Co}=0.018 ; \mathrm{Sn}=0.066 \\
\mathrm{Nb}=0.11 ; \mathrm{Sb}=0.010 ; \mathrm{Ta}=0.063\end{array}$} \\
\hline (B) ST03-1 & 0.0120 & $0 \cdot 0117$ & 0.0118 \\
\hline \multicolumn{4}{|l|}{$\begin{array}{l}\mathrm{C}=0.159 ; \mathrm{Si}=0.46 ; \mathrm{Mn}=0.75 \\
\mathrm{~S}=0.010 ; \mathrm{Cu}=0.67 ; \mathrm{Ni}=0.17 \\
\mathrm{Cr}=3.23 ; \mathrm{Mo}=0.39 ; \mathrm{V}=0.019 \\
\mathrm{Ti}=0.062 ; \mathrm{Co}=0.15 ; \mathrm{Sn}=0.046 \\
\mathrm{Nb}=0.069 ; \mathrm{Sb}=0.011 ; \mathrm{Ta}=0.012\end{array}$} \\
\hline (C) A-1 & 0.0240 & 0.0240 & 0.0243 \\
\hline $\begin{array}{l}\mathrm{C}=1.01 ; \mathrm{Al}=0.01 ; \mathrm{Ni}=4.00 \\
\mathrm{Ti}=0.27 ; \mathrm{Nb}=0.200 ; \mathrm{Pb}=0.036 \\
\mathrm{~W}=0.16\end{array}$ & & & \\
\hline
\end{tabular}

* Average of six determinations

\# Johnson et al 1973

solution was determined by the proposed method. The results show fairly good agreement between the proposed method and the certified value (table 1).

\section{References}

Anderson E and Spreadborough J 1967 Rev. Metall. 64177

Arora H C, Venkateswarlu Ch and Rao G N 1980 Indian J. Chem. A19 500

Armstrong W A, Grant D W and Humphreys W G 1963 Anal. Chem. 351300

Burkin A R 1980 Topics in non ferrous extractive metallurgy in nonhemius, in The extractive metallurgy of deep sea manganese nodules (Oxford: Blackwell Scientific Pub.) p. 42

Cukor P and Weberling S B 1968 Anal. Chim. Acta 41404

Dean A J and Rains C T 1975 Flame emission and atomic absorption spectrometry (New York: Marcel Dekker Inc.) Vol. 3, p. 116

Fassel V A 1960 Anal. Chem. 3219

Hiroshi $O$ and Yukio T 1965 Bunseki Kagaku 14 462; also in Chem. Abstr. 63 6303e

Job P 1928 Anal. Chem. (Paris) 9113

Johnson H N, Kirkbright G F and Whitehouse J 1973 Anal. Chem. 451603

Kinnunen $J$ and Lindsjoe O 1967 Chem. Anal. 5625,76

Kippenhan N and Gschneidner K A Jr 1970 Rare earth metals in steel (New York: Molybdenum Corp. of America)

Kirkbright G F, West T W and Woodward C 1965 Talanta 12517

Kirkbright G F, West T W and Woodward C 1966 Anal. Chim. Acta 36298

Luke C L 1966 Anal. Chim. Acta 36122

Pal B K, Toneguzzo F, Corsini A and Ryan D E 1977 Anal. Chim. Acta 88353

Papa G, Negoire D and Baiulescu G 1959 Z. Anal. Chem. 167329

Poddar S N, Sengupta N R and Adhya J N 1965 Indian J. Chem. 3135 
Pollock E N 1969 Talanta 161323

Poluektov N S, Meskova S B and Melentieva E V 1970 J. Anal. Chem. USSR (Eng. Transl.) 251131

Sandell E B 1959 Colorimetric determination of traces of metals (New York: Interscience) 3rd ed.

Sarma B 1956 J. Sci. Ind. Res. B15 696

Shemyakin F M and Volkova V A 1939 J. Gen. Chem. (USSR) 9 698; also in Chem. Abstr. 32 T369

Trusou L P and Kumanin V I 1963 Liteinoe Proizv 4 34-7; Nucl. Sci. Abstr. 17 3670; Eng. Trans. Russ. Cast. Prod. 4182

Vogel A I 1961 A text book of quantitative inorganic analysis (London: Longman) 3rd ed., pp 543

Welz B 1985 Atomic absorption spectrophotometry (Germany: VCH) p. 291

Zhivopistsev V P and Parkacheva V V 1963 Uch. Zap. Permsk Univ. 25104 